\title{
IDENTIFICATION OF BUSINESS CONSTRAINTS AND MARKETING OF POTATOES IN ACEH'S GAYO HIGHLANDS
}

\author{
${ }^{1}$ Nurmala, ${ }^{2}$ Hafni Zahara, ${ }^{3}$ Sullaida, ${ }^{4}$ Jamilah* \\ ${ }^{1}$ Department of Management, Faculty of Economic, Universitas Malikussaleh, Aceh, Indonesia \\ ${ }^{2}$ Department of Management, Faculty of Economic, Universitas Malikussaleh, Aceh, Indonesia \\ ${ }^{3}$ Department of Agribusiness, Faculty of Agriculture, Universitas Malikussaleh, Aceh, Indonesia \\ ${ }^{4}$ Department of Agribusiness, Faculty of Agriculture, Universitas Malikussaleh, Aceh, Indonesia* \\ *Corresponding author: BTN ASEAN Block Q No. 6 Paloh Lada, Dewantara Sub District, Aceh Utara District \\ E-mail: jamilah@unimal.ac.id
}

\begin{abstract}
This study aims to identify the constraints on potato farming and marketing in the Gayo Highlands of Aceh. The research sample consisted of potato farmers and traders who were involved in potato marketing in Bener Meriah Regency. Determination of the sample of traders is done by snowball sampling technique. The identification of constraints uses a qualitative descriptive approach, while the income analysis uses an analysis of costs and farm revenues. The results showed that there were constraints in potato farming in the form of wilt disease which caused potatoes to be harvested immediately and the fruit produced was smaller. This will have an impact on decreasing the income of potato farming. The relatively high use of pesticides during the rainy season has implications for increasing the cost of potato farming, on the other hand the difficulty of accessing capital causes farmers to enter into potato farming partnerships with collector traders with the provision that potato marketing must be done to these traders. The development of potato farming in the Gayo Highlands of Aceh has encountered several obstacles including fluctuations in potato prices, lack of weed control which has implications for decreasing potato productivity, difficulty in accessing capital which will determine the sustainability of farming, income and farmers' welfare. farmers, namely selling potatoes through collectors, through wholesalers, and selling directly to consumers. Factors that determine farmers' decisions in marketing potatoes are the selling price, farm capital assistance, farm location, and potato quality. Direct marketing of potatoes (3rd type) to consumers is more efficient than other potato marketing channels because it can reduce farming and marketing costs. However this is rare and the sales volume of potatoes is very small.
\end{abstract}

Keywords: constraints, marketing, potato.

\section{INTRODUCTION}

Potato consumption increased up to $46.6 \%$ while fluctuating potato production due to improper cropping patterns, excessive use of pesticides (Adiyoga, 2011), and potato prices decreased during the main harvest so that farmers switched to farming other commodities causing the supply of potatoes to fluctuate as well. Some of the national potato needs are supplied through imports. During 2015-2019 there was a decrease in harvested area and potato production. In 2015 the potato harvested area was 3,247 ha and the production was 70,047 tons with productivity reaching 21.57 tons/hectare. In 2019, the potato harvested area fell to 2,166 ha and production was 26,529 tons with a productivity of 12.25 tons/hectare (BPS Aceh, 2020).

In 2019, the potato harvested area fell to 2,166 ha and production was 26,529 tons with a productivity of 12.25 tons/hectare (BPS Aceh, 2020). Potato production centers are widespread, including the districts of Bener Meriah, Central Aceh, Karo, Simalungun, Humbang Hasundutan, Solok, Garut, Pasuruan, Banjarnegara, Bandung, Kerinci, Wonosobo, Brebes, Probolinggo, South Minahasa, and Malang. Types that are widely grown are vegetable potatoes with varieties of granola, Cipanas, Segunung and Merbabu-17. 
The potato production centers are in the Gayo Highlands, namely Central Aceh Regency and Bener Meriah Regency which are located at an altitude of $800-2,600 \mathrm{~m}$ above sea level. The average productivity of Granola potatoes reaches 30-35 tons/ha using 10 tons/ha of manure, 10 tons/ha of coffee husk waste and liquid manure. The use of certified G4 seeds achieved an average production of 26,364 kg/ha/season (Sayaka, et al., 2011) and showed significant differences in the costs and revenues of potato farmers (Ridwan, et al., 2010). Potato production to meet local market needs in Takengon City and its surroundings, as well as markets outside the region such as Banda Aceh, Lhokseumawe and Medan (export). The selling price of potatoes at the farm level is Rp. $4,500 / \mathrm{kg}$ (at harvest) up to Rp. 7,000/kg (limited potato stock is around 20 tons per day). While the price at the consumer level is around Rp. $8.000 / \mathrm{kg}$ up to $\mathrm{Rp} .12,000 / \mathrm{kg}$. The decline in productivity and the range of selling prices of potatoes at the farmer and consumer level will determine the competitiveness of potatoes and the sustainability of potato farming at the farmer level. In this condition, farming partnerships are a measure of the success of a farming business that can increase farmers' income.

\section{IMPLEMENTATION METHOD}

\subsection{Research sites}

The research location is in the Gayo Highlands of Aceh, precisely in Bener Meriah Regency (Kecamatan Permata and Kecamatan Bukit) with the consideration of being a production center for the Granola and Merah varieties of potatoes.

\subsection{Sampling technique}

Determination of the sample using the Simple Random Sampling technique, namely farmers who cultivate potatoes in the production center area, in Bener Meriah Regency (Permata District and Bukit District). Determination of the sample of traders using the Snowball Sampling technique.

\subsection{Analysis method}

Identification of potato farming constraints was carried out using a qualitative descriptive approach. While supply chain partnerships are carried out by identifying marketing channels, involved marketing agencies, and potato supply chain systems using snowball sampling technique. Analysis of farm income by taking into account the amount of expenses and revenues on potato farming

\section{RESULTS AND DISCUSSION}

\subsection{Identification of Constraints on Potato Farming}

Potatoes are one of the leading commodities in the Gayo Highlands of Aceh after coffee and avocado commodities, but in the field of horticulture, potatoes occupy the main position as a leading commodity, which is generally developed in the Districts of Bukit, Permata, Wih Pesam, Bandar and Bener Kelipah with an area of 738 ha and production of 13284 tons. Based on the land area for the development of horticultural crops, potatoes are mostly done by farmers in Bener Meriah Regency and potato productivity is 18 tons/ha higher than the average potato productivity in Aceh Province, but potato productivity is lower than productivity in East Java Province which reached 25.27 tons/ha. Low productivity is caused by wilt disease, lack of weeding activities, and high water absorption during the rainy season which causes potatoes to rot quickly.

There are 2 types of potato varieties developed in Bener Meriah Regency, namely granola and red potatoes. Red potatoes are richer in carbohydrates and iron, have low water content, and are relatively resistant to disease, but farmers in the study area prefer granola potato cultivation because the demand is relatively high. With low water content, red potatoes are generally processed into potato chips 
Potato commodity is carried out on a smaller land scale, ranging from 0.25 ha to 0.5 ha, considering that potato is a sideline farming and is grown in an intercropping way among other horticultural crops such as leeks, carrots, cabbage, and tomatoes. Generally, farmers cultivate potato granola because it is easier to cultivate, the demand for potatoes is higher and the potatoes do not rot quickly. On the other hand, red potatoes are cultivated by farmers on a narrow land scale because potatoes rot quickly, their skin peels off easily.

Potato farming is also carried out with a profit-sharing system. If the land and capital are issued by the land owner, the profit sharing system between the land owner and the owner is the result of the sale of potatoes (volume of potatoes $x$ selling price of potatoes) after deducting the cost of potato seeds (around Rp. 25,000/kg), then the remaining revenue is divided equally ( $2: 2$ ) between land owners and people.

The obstacles in potato farming include, during the rainy season, leaves often rot and the plants wilt, so pesticides must be given (sprayed) every 3 days. But in hot weather, pesticide spraying is done once a week. If there is leaf rot, it will spread to other plants. In this condition, farmers usually immediately pull out (harvest) potatoes, and the potato yields obtained are in the form of rendang size which can be sold at a price of Rp. $2.500 / \mathrm{kg}$.

The development of potato farming in the Gayo Highlands of Aceh has experienced obstacles including fluctuations in potato prices, lack of weed control which has implications for decreasing potato productivity, difficulty in accessing capital, the absence of potato exporters that will determine income, farming sustainability, and farmer welfare.

Potato production in Aceh's Gayo Highlands is relatively high in the range of 25 tons/ha to 28 tons/ha. Based on the soil texture and weather support for potato growth, potato productivity can still be increased. In terms of production and productivity as well as its ability to meet local markets, it is estimated that potatoes have the opportunity to become a leading export commodity (Yusnidar et al, 2021).

The amount of income shows one level of success of a business (Jamilah, 2017). The cost of land and equipment per hectare in potato farming is Rp. 16,024,500. If the production of rendang/small yellow potatoes of 21 tons/ha has not been able to cover the cost of potato farming. Farmers suffered losses of around 27,013,460. Farmers' profits can be obtained if potato production reaches 31.9 tons. Production of rendang size potatoes in case of plant wilt disease so that potatoes must be harvested early and potato growth has not been maximized. Under normal conditions, potato farming is quite profitable with a profit range of Rp. 15 million to Rp. 67 million per hectare.

Some of the causes of low potato production at the farm level are: (1) caterpillar attacks, (2) high rainfall causes potatoes to be susceptible to rot, (3) lack of cultivation technology development from related agencies, and (4) lack of weeding that hinders potato production. potato production growth. Farmers experience difficulties in developing potato farming due to limited capital lending and difficulty accessing credit, high prices for seeds and fertilizers, high wages, especially potato lansir wages (at harvest) during the rainy season due to rather extreme land conditions. So far, farmers have only relied on capital assistance from collecting traders or doing potato farming with a profit-sharing system. States that farmers' limitations in providing capital and obtaining credit are referred to as structural and cultural weaknesses of farmers so that they find it difficult to develop their farms (Karmana (2005), Jamilah (2014), Jamilah (2017)

Government assistance for farmers in the form of seeds (G2 seed assistance of $800 \mathrm{~kg}-$ $1,200 \mathrm{~kg}$ per farmer group) and fertilizer through farmer groups. The distribution of seeds for farmers is based on the area of land planted with potatoes, ranging from $150 \mathrm{~kg}$ to $200 \mathrm{~kg}$ of potato seeds. The government also carried out breeding efforts for potato seeds but it did not work as it should. Procurement of potato seeds at the farmer level comes from purchasing seeds from local traders, the results of captive breeding of potato seeds in Bandung, and there are also farmers who carry out seed breeding to meet the needs of potato seeds in their farms. The price of potato seeds depends on the quality. G0 seeds range from Rp. 4,000/piece, while G2 costs Rp. 1,250/fruit (1 kg 
contains 12 pieces at a price of Rp. $15,000 / \mathrm{kg}$ ). The type of seed that is mostly used by farmers is the type of G2 seed, the result of captive breeding carried out by farmers.

\subsection{Potato Marketing}

Farmers' decisions in the selection of marketing channels will determine the level of farmers' income (Jamilah 2010a, Jamilah 2010b, Nuhfil dan Jamilah, 2011). Potato marketing at the farmer level is generally through sub-district collectors. In this case, the cost of transportation and sacks (in the form of netting sacks) is borne by the collecting traders. It is then marketed to collectors outside the sub-district. The marketing of potatoes to village collectors is also carried out by farmers to village collectors, but the purchase volume is smaller. There is a partnership that exists between farmers and sub-district collectors based on farm capital assistance from traders with the provision that potatoes (harvests) must be sold to sub-district collectors with lower potato prices (price difference of Rp. 200/kg - Rp. 300/ kg) compared to the market price. The following is a description of potato marketing channels at the research site.

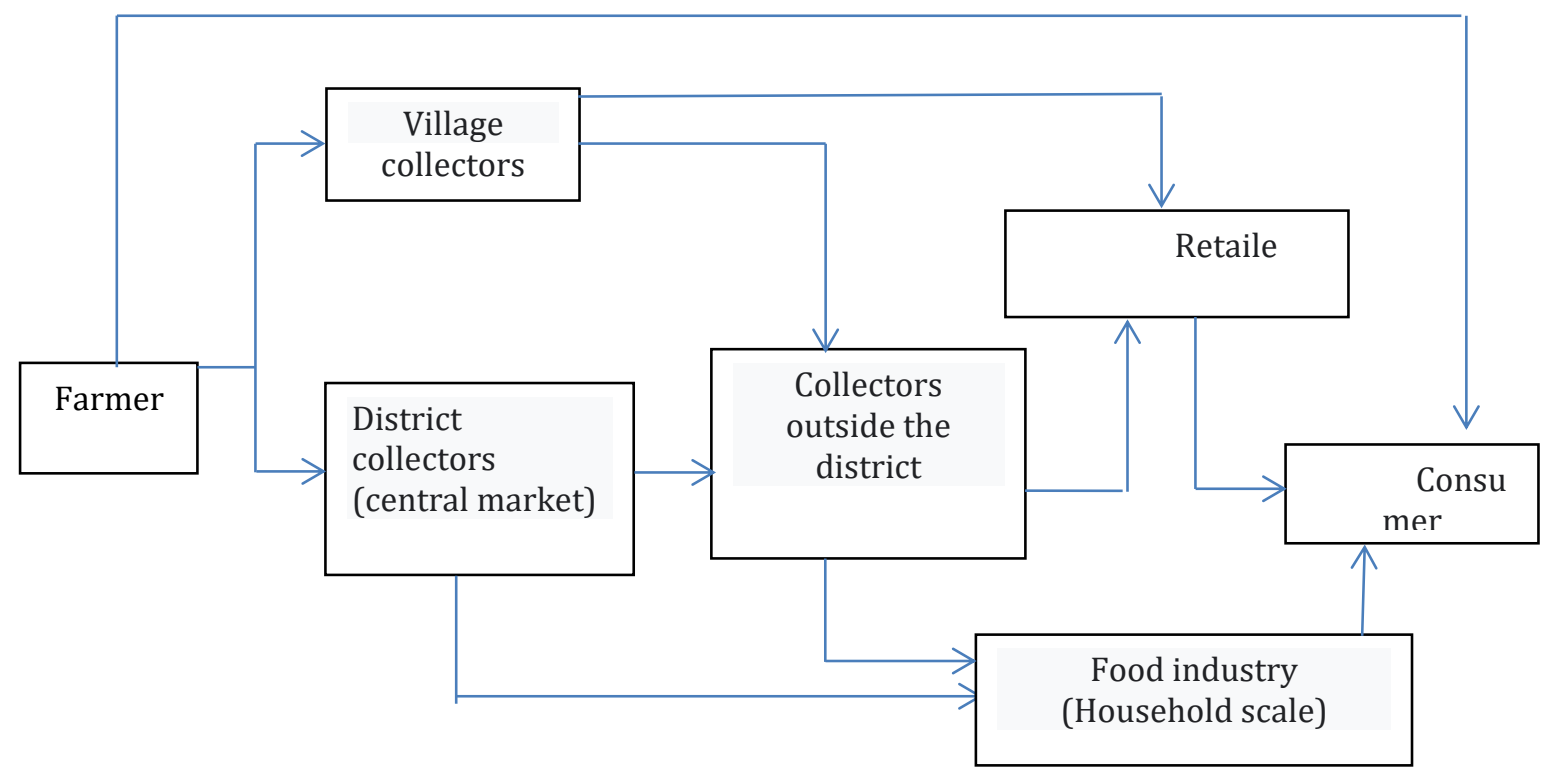

Figure 1. Potato marketing channels in the study area

Bener Meriah Regency has the potential to export potatoes if farmers are able to produce export-oriented organic potatoes. Marketing of jumbo size potatoes is sold by sub-district collectors to wholesalers in North Sumatra and Banda Aceh Provinces. Potato sales from sub-district collectors to outside-sub-district collectors range from 1 ton to 2 tons with a consignment payment system (30\% initial payment of the total purchase. Sales of potatoes to the food industry in smaller quantities, such as french fries business. Retailers make purchases and selling smaller quantities of potatoes in traditional markets.

\section{CONCLUSION}

a. Constraints in potato farming, among others, during the rainy season usually often occurs leaf decay and plants wilt. Leaf rot will spread to other plants. In this condition, farmers usually immediately pull out (harvest) potatoes, and the potato yields obtained are in the form of rendang size which can be sold at a price of Rp. $2.500 / \mathrm{kg}$. The development of potato farming in the Gayo Highlands of Aceh has experienced obstacles including fluctuations in potato prices, lack of weed control which has implications for decreasing potato productivity, difficulty in accessing capital, the absence of potato exporters that will determine income, farming sustainability, and farmer welfare. 
b. There are 3 (three) patterns of potato marketing channels at the farmer level, namely selling potatoes through collectors, through wholesalers, and selling directly to consumers. Factors that determine farmers' decisions in marketing potatoes are the selling price, farm capital assistance, farm location, and potato quality.

c. Direct marketing of potatoes (3rd type) to consumers is more efficient than other potato marketing channels because it can reduce farming and marketing costs. However, this condition is rare and the sales volume of potatoes is very small.

d. Potato marketing to wholesalers occurs when farmers are dependent on farming capital from traders with the consequence that farmers are required to sell potatoes to wholesalers at a lower price than the market price.

\section{REFERENCES}

Adiyoga, W. (2011), "Factors influencing consumer behavior and decisions to buy potatoes, onions, and red chilies" J. Hort., Vo. 21.No (3), pp: 280-94.

Amare M, Cissé JD, Jensen ND, Shiferaw B . (2017), "The Impact of Agricultural Productivity on Welfare Growth of Farm Households in Nigeria: .A Panel Data Analysis", FAO, Rome.

Anwar MR, Liu DL, Farquharson R, Macadam I, Abadi A, Finlayson J, Wang B, Ramilan T. (2015), "Climate change impacts on phenology and yields of five broadacre crops at four climatologically distinct locations in Australia. Agricultural Systems", Vol.132, pp: 133144.

[BPS Aceh] Central Bureau of Statistics Aceh. Aceh in Figures. (2020). http://www.bps.go.id/.

Broll U, Welzel P, Wong KP. (2013). Price Risk and Risk Management in Agriculture. Contemporary Economics. Vol.7. No.2, pp: 17-20.

Directorate General of Horticulture. (2012), "Featured commodity. Jakarta: Directorate General of Horticulture".

Emhar, A. (2014). "Analysis of the Beef Supply Chain in Jember Regency. Agricultural Scientific Periodic Journal", Vol.1 No.3,pp: 53-61.

Fauzan, M. (2016). "Analysis of Shallot Farming Efficiency in the Production Center of Bantul Regency", Research Final Report, Kopertis V, University of Muhammadiyah Yogyakarta, Yogyakarta.

Furqon, C. (2014). "Analysis of Strawberry Agribusiness Supply Chain Management and Performance in Bandung Regency", Journal of Agribusiness Supply Chain Management and Performance Analysis, Vol. 3 No. 2, pp: 111-112.

Harris. (2010). "Growth and production of potatoes at various doses of fertilization", Journal of Agrisystems, Vo. 6. No. 1, pp: 15-22.

Jamilah (2010a), "Study of Marketing Efficiency in Pidie District", Journal of Agripep, Vo.11 . No.1, pp: 9-22.

Jamilah (2010b), "Market Performance Analysis of Leading Agricultural Commodities in Nanggroe Aceh Darussalam", In: National Seminar and Annual Meeting of the Dean of BKS PTN West Region for Agricultural Science, 23-25 May 2010, Faculty of Agriculture, University of Bengkulu.

Jamilah (2014), "Opportunities and Constraints of Horticultural Agribusiness Partnerships in Aceh", Economic Management \& Business,

Jamilah, (2017), "Potential and Performance of SmallHolder Livestock Business in Aceh Province", Jurnal Aplikasi Manajemen, Vo. 15. No. 4, pp: 632-642.

.Karmana, MH. (2005). "The Role of Farmers' Organizations in Supporting Agricultural Revitalization. Symposium on the Implementation of Agricultural, Fisheries, and Forestry",Revitalization Policies for the 48th Anniversary of Padjadjaran University, Bandung. 
Martodireso, S. and W.A. Suryanto. (2001). "Fertilization Technology Breakthrough in the Era of Organic Agriculture, Horticultural Food Crops Cultivation and Plantation". Canisius, Yogyakarta.

Nuhfil and Jamilah, (2011), 'Feasibility and Strategy of Beef Cattle Development for Poverty Alleviation in Aceh", Journal of Management Applications, Vol.9. No. 2, pp: 474-480

Yusnidar, Susanti I, Jamilah, Effendy E, Romano. (2021), Fluctuation of Patchouli Oil Price and Its Effect On Patchouli Aceh Production and Productivity. International Journal of Engineering, Science, and Information Technology. Vo. 1. No. 4, pp: 90-94. 